\title{
University Indigenous Students' Perceptions towards Kichwa, Spanish and English
}

\author{
Jacqueline Guadalupe Armijos Monar ${ }^{1}$, Blanca Narcisa Fuertes Lopez ${ }^{1}$, Jorge Edwin Delgado Altamirano ${ }^{1}$ \& \\ Vicente Marlón Villa Villa ${ }^{1}$ \\ ${ }^{1}$ National University of Chimborazo, Ecuador \\ Correspondence: Jacqueline Guadalupe Armijos Monar, National University of Chimborazo, Ecuador. E-mail: \\ jarmijos@unach.edu.ec
}

Received: November 24, 2017 Accepted: January 18, 2018 Online Published: January 21, 2018

doi: 10.5539/elt.v11n2p131

URL: http://doi.org/10.5539/elt.v11n2p131

\begin{abstract}
Even though there has been a significant advancement in human rights, social justice and social practices around the world; some Ecuadorian indigenous students still struggle against many social and linguistic limitations, especially in Chimborazo province. This research was carried out with 30 Ecuadorian indigenous students who studied English as a compulsory subject for five months. The aim of the study is to explore the general attitudes of indigenous university students about Kichwa, Spanish and English languages in the Universidad Nacional de Chimborazo, at the Political and Administrative Science College. It also aims to find out which language demands more of their attention. Quantitative and qualitative data were collected into three-time stages by applying a questionnaire asking for students' attitudes towards Kichwa, Spanish and English. Participants were asked about their language exposure in each of the mentioned languages. Answers were tabulated using the Statistical Package for the Social Sciences (SPSS) program. The outcomes revealed a substantial difference in the students' attitudes in favor of Spanish language. Students showed a high exposure and attitude percentage towards Spanish language through social interaction with native speakers. Additionally, they listened and read information in Spanish with the most accuracy. The participants have been exposed to Spanish more than 20 years, as well. Conversely, students do not show a significant attitude towards English or Kichwa. Additionally, their social and academic contexts do not demand that the students to speak Kichwa and English, as a priority in students' daily communication.
\end{abstract}

Keywords: attitudes, bilingualism, English, indigenous student, Kichwa, limiting factors, multilingualism, Spanish

\section{Introduction}

\subsection{Context of the Problem}

Some indigenous populations and minority groups face almost the same problems in Ecuador and elsewhere in the world (United Nations Department of Public Information, 2010). It is necessary to remember that socially dominant conditions have not been removed over time. In essence, speakers who are part of a dominant language promote injustice and social inequality which increase social conflict (Oliveros, 2008). In other words, linguistic conflict is the result of social conflict, and linguistic conflict nourishes social conflict. In all latitudes, dominated populations struggle under some social, economic, educational, psychological, and political issues and even the death of their native mother tongues.

Fasold (2014) points out that in the United States of North America in 1990, Congress had approved the Native American Languages Act for preserving and developing native languages. Disappointingly, government did not provide any financial support for preserving indigenous languages.

Cuasialpud (2010) analyzed some Colombian indigenous students who experienced a lack of economic resources, limited high school background knowledge, family problems and cultural issues when attending universities. As a result, they showed a low interest for their future studies. She states "in the Universidad Nacional de Colombia, for example, many indigenous students have failed due to the level of education and knowledge the university requires or expects regular students to have" (p. 138).

Some Mexican indigenous immigrants live under the same conditions such as low literacy levels, economic 
shortage, low educational achievement, deficient housing, a lack of health insurance, including stress and anxiety in a high percentage (Mesinas \& Perez, 2016).

When referring to Quechua language varieties in South America, its speakers find them unintelligible among all varieties from country to country. A research was conducted in Cochabamba-Bolivia, in which indigenous students in a masters program had developed many communicative strategies across their different Quechua varieties in order to facilitate communication among themselves. Communication under Quechua languages took considerable mental effort from their speakers because they experienced difficulties in expressing academic arguments only in Quechua terms. There was no existence or a different lexicon among Quechua varieties in order to express their messages accurately (Luykx, García, \& Julca, 2016).

The vast majority of Ecuadorians speak only Spanish from South America. Monolingualism seems to be the norm amongst them. Linguistically and politically speaking, Kichwa, a language variety from Quechua languages, has not received sufficient standardization and literacy development through time, which is completely different from Spanish language, as a code and, as a number of speakers. Kichwa is spoken about 7\% of the indigenous populations all over the country (Instituto Nacional de Estadísticas y Censos, 2012). Quite frequently, Kichwa has been reduced to a peasant language. Nowadays, there are some attempts to rescue and teach Kichwa proficiently (Chireac, Francis, \& Hadley, 2016). Nonetheless, the indigenous have a strong sense of cultural identity.

The Chimborazo province in Ecuador has the highest number of indigenous population, which is about $38.0 \%$ over the national rate. Also, it has the highest percentage of illiteracy $20.4 \%$ over the national illiteracy rate (Instituto Nacional de Estadísticas y Censos, 2012). Ecuadorian Indigenous students from the highlands are Kichwa native speakers, and Spanish from Andes is their second language (L2). Kichwa is offered and learned in very few bilingual public schools and high schools, especially in rural areas. There are a couple of public universities that teach Kichwa as a subject to achieve an undergraduate program certificate. On the other hand, Spanish is an obligatory language for attending any public university or any academic context. Indigenous students migrate from impoverished rural areas to achieve a profession in urban universities.

Public school Ecuadorian students have been studying foreign languages as compulsory subjects such as English (mostly) and in very few cases French in high school or college; but they have not reached a high proficiency level in those taught languages. They usually receive high grades in language classes. English course approval allows them to get an undergraduate degree.

Specifically, this research was based on 30 indigenous students who attended several majors at the Political and Administrative Science College in the Universidad Nacional de Chimborazo (UNACH), in Riobamba-Ecuador, during March 2017 to August 2017. Unfortunately, their English performance is academically limited, according to Common European Framework standards. A report from UNACH states that, there is not any indigenous university student who has gained a scholarship to study in an English speaking country (Guffante, 2015) since the university was created in 2004; nonetheless, the university offers scholarship opportunities through Erasmus Mundus program, Ecuadorian government through SENESCYT (Secretaría Nacional de Ciencias y Tecnología), Fulbright commission and others, to the whole student population; regardless of any racial, sexual identity or economic background in order to avoid any kind of discriminatory issue. Actually, there are indigenous university students from UNACH who gained scholarships to study in European countries such as Italy and Spain. This confirms that indigenous students have preferred to apply for scholarships where to speak English is not required. Consequently, indigenous students do not seem to be interested in continuing their post- graduate studies at any university where communicating in English is mandatory; even though, English has helped eliminate communication gaps and barriers among nations from different, distant linguistic, social, cultural and geographical backgrounds. There are over 1500 million English speakers over the World as first or second language (L1-L2), and English speakers as a Foreign Language (EFL) (OMICS International, 2013) on the planet.

In this respect, when discussing factors that influence a language learning, it is necessary to take into consideration the socio-economic status of the majority of kichwa speakers. They have been relegated to social, economic, educative better advancement conditions not only a social, political and cultural colonization from pastime, but also at the present time (Walsh, 2003). The linguistic problem of the majority Kichwa speakers is based on some negative influence from their ancestors. In the context of colonial segregation, indigenous have been submitted under Spanish dominance for such a long time. After the Ecuadorian independence from Spain, women had been excluded from cultural and political affairs, racism and indigenous population exclusion were more deepened (Quispe, 2014). 


\subsection{Research Questions}

1). What are university indigenous students' attitudes towards Kichwa, Spanish and English?

2). Do university indigenous students show a significant difference in their attitudes on Kichwa, Spanish and English?

3). What is the effect of indigenous students' attitudes on their English language performance?

\subsection{Research Objectives}

The purpose of the study is to explore the general attitudes of indigenous university students about Kichwa, Spanish and English languages in the Universidad Nacional de Chimborazo, at the Political and Administrative Science College. It also aims to find out which language demands more of their attention.

\subsection{Significance of the Study}

This research is relevant in three aspects. First, it will provide reliable data to continue investigating about indigenous university students' attitudes about Kichwa, Spanish and English languages in Ecuadorian and public universities. Second, it can also be taken as a reference for social-linguistics on what is going on with Kichwa, Spanish and English languages and their current speakers. Furthermore, EFL educators may get a better understanding of indigenous students and their English language expectations and attitudes. Finally, EFL educators and university administrators can gain some insights from the findings and take them into account in encouraging English language learning and teaching.

\subsection{Limitations of the Study}

1) This study only examines the attitudes of those indigenous university learners who voluntarily agreed to answer the surveys. Regrettably, there were some indigenous students who deny the classification of indigenous; even though, they show plenty of language interference between Kichwa and Spanish languages when speaking. An invisibility attitude has been adopted by those university students; in fact, some men had removed their traditional outfits for mestizo ones' instead.

2) 11 subjects preferred to read and answer the applied surveys only in Spanish language rather than English and Kichwa. Some of them argue that they feel more comfortable when reading in Spanish. Apart from that, there were some subjects who confess not being able to read and write in their Kichwa language, they can only listen to and talk to others by using the same code.

\section{Literature Review}

\subsection{Defining Kichwa, Spanish and English Languages}

\subsubsection{Kichwa}

It is a Quechua variety which comes from the second language group Huampuy (Quechua II varieties) (Hornberger \& Coronel- Molina, 2006). It is spoken by Ecuadorian indigenous people living in the Andes Mountains Range and some parts of the Amazon basin. This variety has not only resulted from other former natives and civilized tribes' languages, who used to live before Tawantinsuyu formation, in today's Ecuadorian territory, but also resulting in an ethnic group mixture (Danver, 2015).

Kichwa or Runa Simi is an oral language mainly. The Roman alphabet was incorporated to Kichwa during Spanish colonization. Kichwa's orthography has not been standardized at all. For instance, there is a doubt whether or not to apply three or five vowels when doing language transcription. If the three vowels are included like: a-e and $\mathrm{u}$. They are mostly pronounced like: /æ/, /I/, /U/ (Cerron, 1987).

Written renderings in Kichwa show a high influence from Spanish language. Actually, there are several Spanish and loanwords due to direct contact with Spanish speakers. Additionally, there are couple of English loan words in the Kichwa language too. Nonetheless, there are some educators and activists who have been advocating for standardizing written and spoken language. They promote the elimination of language variations, Spanish loanword exclusion in order to create uniquely Kichwa words. Those would be used in computers and automobiles (Danver, 2015).

Over time, Kichwa has taken part of many endangered and threatened minority languages in contemporary times. "Languages with low prestige lose linguistic functions; languages that lose functions ultimately die" (Palomino, 2015, p. 40). In fact, many Quechua dialects have already disappeared, as explained by Adelaar (1991) in (Hornberger et al., 2006). Based on some statistical data from Instituto Nacional de Estadísticas y Censo del Ecuador (2010), the number of Kichwa speakers was 730.104 . 
Therefore, it is important to mention that the majority of Kichwa speakers are not communicatively competent on it, by applying all four language skills effectively. Mainly, there is a lack of written materials (newspapers, books, magazines and many more). It has limited the Kichwa language diffusion (Hornberger et al., 2006). (The Bible has been translated into Kichwa for evangelization purposes though).

\subsubsection{Quechua}

The roots of Kichwa comes from Quechua. It is divided into dialect families. Proto Quechua has Huaihuashi (Quechua I varieties) and Huampuy (Quechua II varieties). The Quechua language was considered as a lingua franca (Mejía, 2005) throughout the former Inca Empire, known as the Tawantinsuyu, from Colombia to Argentina, before the seventh century. Since there are many dialects, Quechua speakers are unable to communicate effectively among all speakers from South America; in other words, there is not a mutual intelligibility. According to Cerron (1987) he states that there were approximately 8.354.125 Quechua speakers distributed in seven countries from South America such as Ecuador, Peru, Bolivia, Argentina, Colombia, Brazil and Chile. Nowadays, Quechua varieties and cultures are powerless, kind of silenced under the name of globalized modernism (Back, 2015).

In the same linguistic framework, the Quechua language structures are blurred. For instance, words are built up from basic roots, following suffixes. Words are characterized by inflectional and derivational morphology. Quechua varieties do not specify gender, if needed, auxiliary words can be used in order to identify male and female. Verbs are categorized as transitive, intransitive and equational or existential. Quechua has two past tenses which are indicated by using with two different suffixes. Its sentence structure is identified by subject+object+verb (word order). There are seven pronouns. Adjectives are placed before nouns (UCLA, n/d), (Cerron, 1987), and (Hornberger et al., 2006).

A study conducted by Boas 1911 reported in Duranti (1997) explains that "American Indian language sounds were not pronounced as accurately as in European languages" (p. 54). In fact, AILLA (2017) demonstrates that some indigenous languages from Latin America own an increased number of sounds than European languages, so much so that it is difficult to transcribe them by using European alphabets. For instance, Yuwe language has thirty-seven consonants including twenty vowels. Spanish possesses twenty consonants and five vowels.

\subsubsection{Spanish}

It is derived from Latin language (Romance languages) which belongs to the ancestor of the Italic language branch; its main linguistic trunk is Proto-Indo-European family. Modern Spanish language has a great amount of vocabulary from other languages such as Greek, Arabic (8\%), Basque, Gothic, French, Italian, Occitan, Sardinian, Catalan, Leonese, Aragonese, Occitan Portuguese, Nahuatl, Quechua languages, including Germanic languages, the last ones in a minor percentage. The highest amount of vocabulary comes from Latin (Ralph, 2002).

Spanish was brought to the Americas, and to some territories in Africa, Oceania, and the Philippines through Spanish colonizers, in the early XVI century. American Colonized territories communicated with European-Spanish crown by using Spanish. When on the American continent, Spanish came into contact with many indigenous languages (Instituto Cervantes, 2012).

Nowadays, Spanish is among the most spoken languages in the world, including in many important organizations on the planet such as the United Nations, the European Union, the Organizations of American States, and the Union of South American Nations among others. It is estimated that there are 517.423.452 Spanish speakers on the planet. Particularly in Ecuador, there are 14.024.376 Spanish speakers (Spanish Language Domains, 2014).

Through time, Spanish has varied linguistically and geographically. Castilian Spanish was the standardized variety (Ralph, 2002). There are significant differences between Peninsular Spanish and Spanish from South America, especially in the use of diminutive suffixes (Pountain, 2016). Today, Asociación de academias de la Lengua Española (ASALE) and Real Academia Española (RAE) provide the standardized Spanish language norms (Pountain, 2016).

\subsubsection{English}

In the endeavor to define what the English language is, it is essential to mention its sociolinguistic origins. Based on some research, around the fifth century A. D, three small tribes like Angles, Saxons and Jutes fused their speeches, and created English which was empowered by England. English, along with other European languages, is classified within Proto-Indo-European family. Particularly, the English language was derived from West Germanic language branch. English has three periods of language evolution: Old, Middle and Modern, which is 
subdivided into the Early Modern and Late Modern English (Algeo \& Acevedo Butcher, 2013). It shows a high world status because of the former British geographical-historical and socio-cultural colonial expansion throughout the world, and the leading economic and political power of the United States in the twentieth century (Crystal, 2003).

Historically, English has survived through generations undergoing linguistic and significant modifications over time. For Shukla and Connor Linton (2006) "All languages adapt to meet the changing contexts and needs of their speech communities" (p. 276). In the same context, Algeo et al., (2013) claim that "Language change is natural because a language system is culturally transmitted" (p. 14). For Romaine (2000), Holmes (2013), and Fasold (2014) the changes of English language can be seen in its phonology, morphology, syntax, semantics and pragmatics. Additionally, English shares common word stock (cognates), as well as phonetic and grammatical traits with other Proto-Indo-European languages. It has also a great amount of borrowed vocabulary from several languages in contact, which do not necessarily belong to Proto mentioned family. Syntax structure is not relatively complicated, if the word order formula is applied. For instance: Who + what + where + when + how + why. This sentence arrangement can be interchangeable like: Who + what + where or Who + what + why and so on. For Cristal (2003) "English does not have a lot of endings on its words, nor do we have to remember the difference between masculine, feminine, and neuter gender, so it must be easier to learn" (p.7).

These days, English is seen as a Global language or Lingua franca which allows speakers to get access to updated and a great variety of information about technology, scientific advance research, industry, political and economic growth, commerce, learning language materials, education, international relationships, cultural and social interactions, media, press, advertising, broadcasting, cinema, popular music, international travel and safety, and many others; even minority languages can be researched on the internet by means of English language, and among many. As Crystal (2003) affirms "English has become the normal medium of instruction in higher education for many countries and is increasingly used in several where the language has no official status" (p. 112). Therefore, translation is put aside since it is not very reliable from one language speaker to another, including its high cost (Crystal, 2003).

In the same way, "the number of people worldwide learning English is steadily increasing, to the point where Kachru (1996) estimates that there are four non-native English speakers for each native English speaker" (Alseweed, 2012, p. 42).

Because of the significant growth number of non-native English speakers, a variety of Englishes are emerging on the planet (Kaur, 2014). In this regard, having an English proficiency is a political, business and academic demand over the world. The number of English students will have increased around two billion people by 2020, as it is stated by Clarke (2012) reported in Wang (2017).

\subsection{Advantages of Bilingualism or Multilingualism}

Bilingualism or multilingualism promotes metalinguistic awareness and has a positive impact on social and academic achievements. For that reason, bilingual or multilingual people are a unique combination thanks to multi competences (Saville, 2006). High L2 achievers are usually those who started at their earliest childhood (Lightbown \& Spada, 2006).

\subsubsection{Three Major Limiting Factors against Bilingualism or Multilingualism Achievement}

A L2 learner usually must overcome some linguistic, social and psychological and universal phonological constraints, including each one of the individual acquirer's circumstances like age, its social consequences, motivations and prior linguistic experiences (García \& García Lecumberri, 2003) in order to achieve a bilingual or mutilingual performance. The presence of Negative interference (Interlingua) and fossilization, a lack of L1 literacy level, and a lack of language exposure (input) straiten to achieve an outstanding bilingualism or multilingualism.

A limited Communicative competence is caused by Negative interference and Fossilization factors which are part of Interlingua conceptualization. Trawinski (2005), simplifies interlanguage as "a language system which the learner constructs in the process of SLA, referring to both L1 and L2" (p. 86); that is, a positive language transfer to develop cognitive association. On the other hand, a Negative interference limits function language components such as phonology, vocabulary, morphology, syntax, discourse, orthography and semantics (Saville, 2006). Lado in (Gass \& Selinker, 2008) states that "structures that are different will be difficult because when transferred they will not function satisfactorily in the foreign language and will, therefore, have to be changed (p. 96). Regrettably, Fossilization is another limiting factor when dealing with L2 achievement. Fossilization is defined as "a phenomenon of the arrested development of interlanguage" (Trawinski 2005, p. 55). A L2 learner 
develops fossilization phenomena in some aspects of the language such as pronunciation, formulaic speech, structural and semantic simplification, acquisition of morphemes, and complex sentence structures. L2 learners fossilize errors when there is not an adequate monitoring during the L2 language instruction, feedback, attitude or motivation, including lack of understanding (Trawinski, 2005). Mueller (2012) found that the lack of access to Universal Grammar (UG) is other important factor which contributes to fossilization because L2 learners' acquisition cannot be completed.

Secondly, a lack of L1 literacy level influences in Second Language Learning Acquisition. The level of communicative skills and enabling skills in L1 define student's L2 effective achievement. Literacy levels reflect the way that individuals approach a second language, based on their classroom experiences. Students who have already received a formal education have better communicative and interaction skills. They make better cognitive and effective connections in order to reach the L2 language structure and its components (Mueller, 2012). Having low literacy skills, L2 learners reject to adjust to other cultures; especially, when analyzing written production and cultural aspects of high text-based society (ibid). For that reason, the ability to read and write in L1 have a tremendous impact on someone's ability when learning and acquiring a target language. In concordance with a prior research, Peterson and Siegal (1995) who are cited in (García \& García Lecumberri (2003) state that when a learner has not received sufficient L1 input during his early ages, it will have a negative impact on his general and cognitive effects later.

A third limiting factor is the lack of language exposure (input). Brown (2001) believes that the amount of effective and free voluntary reading extension in the target language determines reading ability, linguistic competence, vocabulary, spelling and writing and language proficiency itself. To Newton (2009) "learning is dependent on the quality of reading and listening skills, and is affected by background knowledge". In that sense, knowledge and skills are part of an accumulative process towards new learning acquisition language of the target language (Gass \& Selinker, 2008). Krashen in Ellis (1994) affirms that "Learners progress along the natural order by understanding input that contains structures a little bit beyond their current level of competence" (p. 273). Therefore, speaking is the result of how much more interesting and comprehensible input the learner has gained during his life. García and García Lecumberri (2003) strongly believe that meaningful interaction and meaning negotiation and long language exposure promote acquisition in a L2. Regrettably, if the target language does not have an immediate or an everyday application in L2 learners' direct social context, their language sensibility and intelligibility decrease significantly (Saville, 2006).

\subsection{Attitudes}

According to Pearson Education Limited (2007) attitude is "the way you behave toward someone or in a particular situation, especially when this shows how you feel" (p. 89). Attitudes can be divided into three components: Affective, behavioral and cognitive components. A stronger attitude often affects behaviour (McLeod, 2014).

\subsection{Status of Indigenous Peoples as Students}

A recent study carried out by British Council (2015) reveals that Ecuadorians face economic inequalities, hence those living in rural areas support their home economy on agriculture mostly. Access to the internet is quite limited in these territories.

The Instituto Nacional de Estadísticas y Censos (2012) has reported that the Chimborazo province has the highest percentage of indigenous population, including the highest percentage of poverty concentration in Ecuador. Ecuadorian indigenous people who migrate from rural areas in the highlands to in and around urban centers, have lost their culture and language mostly. Consequently, for developing social interactions, they have adopted the Spanish language (Danver, 2015). "Although strong local variants in dress and dialect persist in Ecuador, the indigenous have lost much of their linguistic, religious, and cultural distinctiveness" (Danver, 2015, p. 130).

\subsection{Previous Studies on People' Attitudes towards Kichwa, Spanish and English Languages}

Holmes (2013) explains that bilingual people select to use a particular code depending on topic discussion, settings and addressee. Dominant languages are spoken in work and school domains mainly; meanwhile, a native language takes place in the family domain. A study conducted by Labov (1972) cited in Schilling (2013) concludes that speakers from low socioeconomic classes use hypercorrection patterns in order to reduce stigmatization and the desire for upward social mobility by speaking "correctly".

As it was stated earlier, Quechua dialects are mainly oral which have allowed to transmit knowledge through oral tradition. Contrary to what one might expect, Andean oral narrative presents a fundamental element for the 
formation and construction of social being; thus, individuals and culture feedback maintain the correct functioning of the society in which both are inserted, (the translation is mine) (Gil, $\mathrm{n} / \mathrm{d}$ ).

Conversely, there is an ambiguous ideology in order to support bilingualism among indigenous. Most impoverished parents send their children to receive formal instruction in Spanish speaking and public institutions. They believe that indigenous have better opportunities to reach social advancement and mobility. One answer comes from Saroli (2009) who suggests that Intercultural Bilingual Education programs mismatch between community members' attitudes and how those programs are designed and carried out by governments. It is the same perception for Maya (2014) who supports that intercultural radio programs are not designed under indigenous' leadership and expertise. The teaching and learning content do not focus on interculturality either.

In the social interaction setting, Balderston, Gonzalez, and Lopez (2002) stress that "where access to non-traditional jobs, Western education and political influence have allowed integration of indigenous peoples into national economies and power structures, the continuance of separate identities surprised national planners" (p. 535). Actually, "The language attitudes of the Spanish speakers and speakers of indigenous languages reflect hierarchical relationship" (Hornberger et al., 2006, p. 14). Furthermore, "Indigenous language speakers frequently opt not to use their language in many situations in order to avoid the stigma attached to speaking it, a tendency referred to as linguistic shame or linguistic asphyxia" (ibid). Addressing this issue, speaking Spanish rather than Kichwa demonstrates a lack of loyalty to their own native language, plus a significant stigmatization (Hornberger et al., 2006). Surprisingly, even though some college indigenous students are limited in Spanish and Kichwa (Romero et al., 2017), they do not deny their ethnic identity. "Despite the language loss, most continue to self-identify as indigenous" (Balderston et al., 2002, p. 535).

Internationally speaking, Crystal (2003) supports that "English is now so widely established that it can no longer be thought of as 'owned' by any single nation" (p. 26). There are students of English as a second or foreign language in all five continents; however, their attitudes make the difference when attempting to become proficient on it.

Wang (2017) conducted research on a Chinese student population. He found that Chinese women, living in coastal region, are highly proficient in English. They evidence in their education-language and skill-language complementarity. Additionally, he found significant economic difference returns to English among residents, migrants and locals from urban and rural areas. Those living in rural areas have low economic returns due to their low English proficiency. He concluded that English learning curriculum has to be re-evaluated due to a high English learning demand.

In the Ecuadorian context, there are many more students of English than Kichwa in all public sectors. The British Council (2015) estimates that there is at least 1.2 million English language learners in primary, secondary public schools. Meanwhile in 2015 there were around 736.000 university students (EcuadorUniversitario.com, 2016). Most of them are in Ecuador's capital. As it is seen, English language has received important government attention through reform process and education policy, more than native languages have received.

Based on the British Council (2015), there is a high demand of proficient English speakers in the industry field in some provinces such as Pichincha (58\%), Guayas (20\%), Azuay (15\%), Loja (4\%), El Oro (3\%). The (25\%) is the highest share, which is in distribution, logistics, transport and wholesale and hospitality. However, there is a significant shortage of well-qualified, properly-trained and experienced English language educators who have to manage large class sizes and a lack of teaching-learning resources.

Furthermore, because of a limited number of researchers and lecturers in Ecuadorian university levels, the English language is not promoted to use for scientific research purposes, especially in rural universities (British Council, 2015).

Despite economic returns, learning English proficiently represents high cost to study it; not everybody can have access to government-funded programs (British council, 2015), or from foreign organizations. In short, many Ecuadorians earn US $\$ 386.00$ as a monthly wage, hence they are not able to afford English advancement classes, traveling abroad for being exposed to the target language, learning materials, devices, and many others.

\section{Method}

\subsection{Participants}

This study was carried out in the Universidad Nacional de Chimborazo (an academic semester), in the Chimborazo province, Ecuador. There were 30 indigenous students, in university, whose native language is Kichwa. Spanish from South America is their second language; meanwhile, English, as a foreign language, is learned as a compulsory subject in the mentioned university. After finishing the sixth English level, students get 
a B1+ level certification. The students study a total of six contact hours of general English (survival English) per week. The 30 indigenous students agreed to answer questionnaires voluntarily in order to express their attitudes on Kichwa, Spanish and English languages. Conversely, there were other indigenous students who avoided participating in the project by saying "No thanks. I am not indigenous", even though they showed Kichwa-Spanish interferences and physical features. They simply denied participation (mostly male). The participants attended different majors and semesters such as: Accounting and Auditing, Economics, Law, Commercial engineering and Social Communication. All of them are part of Political and Administrative Science College. There were 22 female and 8 male undergraduates; their ages were 18-26, (mean age 21); they had been taught English from 1 to 5 years under a Likert Scale.

\subsection{Measures and Research Design}

Description of the instrument in order to collect data.

The process of questionnaire construction and validation was carried out by the following procedures. Firstly, some literature review was covered in order to identify what mechanisms are part of language exposure by using a reading record template. Secondly, the information obtained from the literature review allowed to create a sequence of four questionnaire drafts, including Kichwa and English translation. Thus, the questionnaire reviewing process was developed by four experts twice. Then, the reviewed questionnaire was applied to two different groups of students with the same characteristic of the target group in two different colleges at the same university. Finally, the fourth questionnaire was polished by taking into account students' written feedback in the applied questionnaires.

The questionnaire was designed and divided into three sections, consisting of three types of questions. The first section asks for General attitudes of indigenous students towards Kichwa, Spanish, and English, based on 12 closed questions to be answered under the Likert's scale (never, seldom, sometimes, almost always and always). The second section asks for students' Kichwa, Spanish and English language exposure, based on 3 questions under time and length scale. The third section asks for Students' topic preferences for reading, listening and social interaction activities, based on 3 opened-ended questions.

Quantitative data was collected in three stages by applying three questionnaires with students. In the first stage, a questionnaire was administered to 30 students with the purpose of finding out their attitudes about their Kichwa language exposure.

The second stage consisted of administering a second questionnaire to the same students and number. It had the exact purpose as the first questionnaire. There were 18 statements (12 questions with the Likert' scale, three open-ended questions, and three questions about time and length language exposure). It asked about Spanish language exposure instead. It was administered two weeks after of the first one.

A third questionnaire was administered after two weeks after the second questionnaire application. The questions of this questionnaire were the exactly same as the two previous ones; however, it asked about English language exposure.

Contrary to what one might expect, 11 indigenous students answered the three questionnaires in Spanish only, because the respondents felt more comfortable using Spanish rather than English or Kichwa. They confessed only to speak and listen to Kichwa language; however, they did not know how to read and write in their own mother tongue. What is more, they struggled to understand the second questionnaire, which was written in English; in some cases, they wanted to hear the translation of some words into Spanish.

Finally, Statistical Package for the Social Sciences (SPSS) program processed the gathered data through variables and frequencies into statistical framework.

\section{Findings and Discussion}

The gathered data from the participants' attitudes is tabulated in Table 1. 
Table 1. University indigenous students' attitudes of their exposure to Kichwa, Spanish and English

\begin{tabular}{|c|c|c|c|c|c|c|c|c|}
\hline \multirow[t]{2}{*}{ Components } & \multicolumn{2}{|c|}{ Statements } & \multicolumn{2}{|l|}{ Kichwa } & \multicolumn{2}{|l|}{ Spanish } & \multicolumn{2}{|l|}{ English } \\
\hline & & & 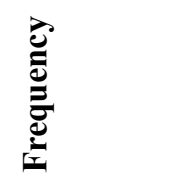 & 营 & 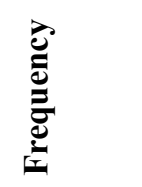 & 营 & 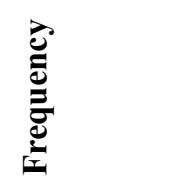 & 窇 \\
\hline \multirow{12}{*}{$\begin{array}{l}\text { General } \\
\text { attitudes of } \\
\text { indigenous } \\
\text { students } \\
\text { towards } \\
\text { Kichwa, } \\
\text { Spanish and } \\
\text { English }\end{array}$} & 1 & $\begin{array}{l}\text { Language use frequency in } \\
\text { classroom. }\end{array}$ & Never & 46.7 & Always & 70 & Seldom & 40 \\
\hline & 2 & $\begin{array}{l}\text { Satisfaction frequency with } \\
\text { daily progress in class }\end{array}$ & Never & 43.3 & Always & 60 & Sometimes & 36.7 \\
\hline & 3 & $\begin{array}{l}\text { Listening frequency of the } \\
\text { auditory material in class. }\end{array}$ & Never & 66,7 & Always & 60 & $\begin{array}{l}\text { Almost } \\
\text { always }\end{array}$ & 36.7 \\
\hline & 4 & Reading frequency in class & Seldom & 33.3 & Always & 66.7 & Sometimes & 46,7 \\
\hline & 5 & $\begin{array}{l}\text { Frequency with which the } \\
\text { teacher speaks to teach. }\end{array}$ & Never & 76,7 & Always & 76.7 & Always & 40.0 \\
\hline & 6 & $\begin{array}{l}\text { Frequency with which the } \\
\text { language is understood when the } \\
\text { teacher develops his class. }\end{array}$ & Never & 46.7 & Always & 83.3 & Sometimes & 53.3 \\
\hline & 7 & $\begin{array}{l}\text { Frequency with which } \\
\text { indigenous student uses internet } \\
\text { to download audios and } \\
\text { readings. }\end{array}$ & Never & 46.7 & Always & 66.7 & Sometimes & 36.7 \\
\hline & 8 & $\begin{array}{l}\text { Frequency with which } \\
\text { indigenous student reads: news, } \\
\text { career studies, health, sports } \\
\text { outside class. }\end{array}$ & Never & 56.7 & Always & 30 & Never & 60 \\
\hline & 10 & $\begin{array}{l}\text { Frequency with which } \\
\text { indigenous student listens to: } \\
\text { news, career studies, health, } \\
\text { sports, films, documentaries, } \\
\text { music videos outside class. }\end{array}$ & Sometimes & 30.0 & Always & 40 & Seldom & 36.7 \\
\hline & 12 & $\begin{array}{l}\text { Frequency with which } \\
\text { indigenous student interacts } \\
\text { personally with native people } \\
\text { outside class. }\end{array}$ & Sometimes & 36.7 & Always & 70 & Never & 56.7 \\
\hline & 13 & $\begin{array}{l}\text { Frequency with which } \\
\text { indigenous student uses any } \\
\text { social networks to virtually } \\
\text { interact with anyone who } \\
\text { speaks: }\end{array}$ & Never & 33.3 & Always & 46.7 & Never & 53.3 \\
\hline & 14 & $\begin{array}{l}\text { Frequency with which the } \\
\text { teacher applies: games, group } \\
\text { discussions, dramatizations, } \\
\text { classroom projects, group } \\
\text { workshops, group work outside } \\
\text { the classroom, spontaneous } \\
\text { conversations, and exhibitions } \\
\text { as social interaction activities. }\end{array}$ & Never & 70.0 & Always & 46.7 & Sometimes & 33.3 \\
\hline
\end{tabular}

Source: Questionnaire and results, section 1 under Likert scale. Authors: Researchers 
Table 1 details information about the first research question "What are university indigenous students' attitudes towards Kichwa, Spanish and English?" As it can be seen on the table, indigenous students are highly exposed to Spanish language rather than the other two languages. Also $83.3 \%$ of the students understand it when their teacher develops their class. A $70 \%$ of the students use Spanish in classroom. Besides, $70 \%$ of indigenous students always interact personally with native Spanish speakers outside class. Students do a $66.7 \%$ of reading in Spanish during class. Additionally, $66.7 \%$ of indigenous students always download audios and readings in Spanish. A $60 \%$ of the students show satisfaction in their Spanish daily advance in class. Students listen to auditory material in class in a $60 \%$. Moreover, $46.7 \%$ of them always use social networks to interact virtually with Spanish speakers. In the same framework, they always listen to a variety of subjects outside their class; it represents a $40 \%$ of the sample. Likewise, students always read outside the class. It represents $30 \%$ of the population.

The results show that there is a lack of real language exposure with English native speakers through social interaction in UNACH. In fact, they do not experience the real difference between interacting with a native speaker and interacting with their teachers in college since the university does not have English native teachers in its staff. English native speakers, especially if they are educators, seem to be more tolerant and flexible with students' mistakes. Consequentially, the learning environment turns more relaxing. Students learn more about their native teachers' culture, because they are ambassadors of their own culture (Alseweed, 2012). Incorporating real language exposure motivates to meaningful and real language learning (Che \& Yunus, 2014).

Table 2. Time and length language exposure to Kichwa, Spanish and English

\begin{tabular}{|c|c|c|c|c|c|c|c|c|}
\hline \multirow[t]{2}{*}{ Component } & \multirow[t]{2}{*}{$\mathbf{N}^{\circ}$} & \multirow[t]{2}{*}{ Statements } & \multicolumn{6}{|c|}{ Time and length } \\
\hline & & & Kichwa & & Spanis & & English & \\
\hline \multirow{3}{*}{$\begin{array}{l}\text { Time and } \\
\text { length } \\
\text { exposure } \\
\text { towards } \\
\text { languages }\end{array}$} & 16 & $\begin{array}{l}\text { Number of daily listening } \\
\text { hours }\end{array}$ & $\begin{array}{l}\text { From } 2 \\
\text { to } 4 \\
\text { hours }\end{array}$ & $53.3 \%$ & $\begin{array}{l}\text { More } \\
\text { than } 4 \\
\text { hours }\end{array}$ & $83.3 \%$ & $\begin{array}{l}\text { From } 1 \\
\text { to } 2 \\
\text { hours }\end{array}$ & 33.3 \\
\hline & 17 & $\begin{array}{l}\text { Number of daily reading } \\
\text { hours outside class }\end{array}$ & $\begin{array}{l}\text { From } 0 \\
\text { minutes } \\
\text { to } 1 \\
\text { hour }\end{array}$ & $50.0 \%$ & $\begin{array}{l}\text { More } \\
\text { than } 4 \\
\text { hours }\end{array}$ & $46.7 \%$ & $\begin{array}{l}\text { From } 1 \\
\text { to } 2 \\
\text { hours }\end{array}$ & $50.0 \%$ \\
\hline & 18 & $\begin{array}{l}\text { Starting year to learn a } \\
\text { language }\end{array}$ & $\begin{array}{l}\text { More } \\
\text { than } 20 \\
\text { years } \\
\text { ago }\end{array}$ & $53.3 \%$ & $\begin{array}{l}\text { More } \\
\text { than } \\
20 \\
\text { years } \\
\text { ago }\end{array}$ & $60.0 \%$ & $\begin{array}{l}\text { From } 1 \\
\text { to } 5 \\
\text { years } \\
\text { ago }\end{array}$ & $53.3 \%$ \\
\hline
\end{tabular}

Source: Questionnaire and results, section 2 under time and length scale. Authors: Researchers.

The findings from Table 2 provide an answer to the second research question "Do university indigenous students show a significant difference in their attitudes on Kichwa, Spanish and English?"

The statistical analysis of the data shows a substantial difference in indigenous students' attitudes towards Kichwa, Spanish and English language exposure. It means that, they daily listen to Spanish language in 83.3\% which accounts for more than 4 hours. In addition, they have been exposed to the Spanish language for more than 20 years. It accounts for a $60.0 \%$ of the respondents. Similarly, their daily reading hours outside class represents a $46.7 \%$. It is clear that there is a high percentage of Spanish language exposure by those college indigenous students. Crystal (2003) suggests that there are around 1.5 billion people on the planet who are proficient in English. Consequently, that number will have increased by 2000. However, the studied indigenous do not show a significant attitude to learn neither English nor Kichwa.

When a language is heard and spoken frequently by some community members, it is because that language is much more valued and better used among them, compared with other codes in the same community (Lightbown $\&$ Spada, 2006). They show interest in the Spanish language through extensive reading and listening daily. Those activities are mainly done when the readable and listening information is familiar (previous knowledge) to them. Learners feel attracted to understand the new input, when language features are known in a $95 \%$ to $98 \%$ (Newton, 2009). In this respect, students find meaning-focused input on comprehending and achieving knowledge and 
possibly enjoyment from the reading and listening materials. Enough vocabulary repetitions through readings enable L2 learners to reach large quantities of input, as it is suggested by Nation and Wang (1999) in (Newton, 2009). Similarly, extensive listening helps L2 learners to acquire vocabulary, become better readers, acquire good speaking habits, pronunciation and social interaction skills as well (Harmer, 2011). Eaton (2011) concluded on her research that a fluent Second language achievement depends on how 10.000 hours are qualitatively distributed to study and practice a new language.

Certainly, L2 readers put aside their books, if they do not accomplish readers' personal expectations, interests, needs and likes. By way of example, two-hundred and forty-four Iranian students from high school do not consider their English textbooks as a rewarding resource to learn English since they did not cover students' needs and their authentic materials were limited too (Rahimi \& Hassani, 2012). Subsequently, a lack of input does not allow L2 learners to comprehend their target language, especially if they are L2 beginners. Students with a limiting input do not show an appropriate level of confidence at the moment of reading, listening and interacting with others (Harmer, 2011).

In the studied scenario, students do not show a motivational power for doing extensive reading and listening neither Kichwa nor English since there are not self-access centers or programs in UNACH or in any local area, where they can find available materials and do some sharing reading and listening report while interacting with others in the target language outside their classrooms. One person's output can be another person's input (Newton, 2009). Receptive and productive skills always nourish one another in a variety of ways (Harmer, 2011)

Age is other salient factor in this research, in an average, $53.3 \%$ of the indigenous students have started learning English five years ago, which limits an effective language proficiency, a native-like-pronunciation at least. Yule (2010) and García and García Lecumberri (2003) stress the importance of learning a language at early ages (Critical period hypothesis), in fact after puberty, learning a second language will demand much more work, especially to reach $\mathrm{L} 2$ accent.

Table 3. Students' preference topics on Kichwa, Spanish and English

\begin{tabular}{|c|c|c|c|c|c|}
\hline Component & $\mathbf{N}^{\circ}$ & Statement & Kichwa & Spanish & English \\
\hline \multirow[t]{3}{*}{$\begin{array}{l}\text { Students' attitudes } \\
\text { for Reading, } \\
\text { listening and } \\
\text { social interactions } \\
\text { categories. }\end{array}$} & 9 & $\begin{array}{l}\text { Personal preference } \\
\text { topics for reading } \\
\text { in... }\end{array}$ & Bible & $\begin{array}{l}\text { - According to their } \\
\text { majors } \\
\text { - National news } \\
\text {-Entrepreneurship } \\
\text { - Innovation }\end{array}$ & $\begin{array}{l}\text { - Readings } \\
\text { exercises in } \\
\text { English classes }\end{array}$ \\
\hline & 11 & $\begin{array}{l}\text { Personal preference } \\
\text { topics for listening } \\
\text { in... }\end{array}$ & $\begin{array}{l}\text {-Christian music } \\
\text {-Videos about } \\
\text { indigenous } \\
\text { culture }\end{array}$ & $\begin{array}{l}\text { _ Local music } \\
\text { - According to their } \\
\text { majors } \\
\text { - National news } \\
\text {-Entrepreneurship } \\
\text { - Innovation }\end{array}$ & $\begin{array}{l}\text { - English } \\
\text { language } \\
\text { tutorials } \\
\text { - Documentaries }\end{array}$ \\
\hline & 15 & $\begin{array}{l}\text { Activities that the } \\
\text { teacher performs for } \\
\text { social interaction }\end{array}$ & None & $\begin{array}{l}\text { - e-learning } \\
\text { video-conferences } \\
\text { - Conferences } \\
\text { - Workshops } \\
\text { - Documentaries }\end{array}$ & $\begin{array}{l}\text { - Video } \\
\text { conferences } \\
\text { - Games } \\
\text { - Role plays }\end{array}$ \\
\hline
\end{tabular}

Source: Questionnaire and results, section 3, open ended questions. Authors: Researchers.

The Table 3 answers the following question, what is the effect of indigenous students' attitudes on their English language performance?

Since the studied indigenous students do not learn English as it should be, their language performance is basic or unsatisfactory. Unfortunately, their dominant social context limits their motivation to reach English learning 
independence and its immediate implementation. Then, it will take much more time and effort to learn and acquire English proficiently, including social and academic opportunities and economic returns. Consequently, they will continue doing what Schilling (2013) argues, indigenous students speak a language depending on social context formality, the addressee, and social-psychological factors in order to accommodate, separate or project a wishing image or speech. In other words, when indigenous migrate to urban centers, they adopt other linguistic attitudes from the dominant group in order to reach "social prestige" (Corral, 2015). Therefore, Kichwa does not have enough social-linguistic room in urban areas; actually, there is a dramatic extinction in Highlands and Amazon regions, in Ecuadorian territory (Castillo, 2017) now.

As evidence, the university (UNACH), where students are taking part of, does not demand that students take an entry or exit English language exam. Pan (2009) has reported that exit examination provides positive feedback to college administrators. He identifies that government increases financial support in order to promote college students' pass rate. More educational resources and facilities are provided to encourage students' English improvement. Curricula and lesson plans are more effective in order to fulfill students' needs and proficiency levels. Students are allowed to graduate if they pass their English test. For that reason, students must develop autonomous learning for receiving a proficiency test certificate. In addition, teachers combine lesson content and proficiency test content, including extra classes and educational resources for a solid language foundation. Nonetheless, contributing to students' success on English certification demands active involvement and diligence from all members.

In a broad and national sense, the British Council (2015) points out that one limiting factor to learn English is a low income; private courses and programs cost around US\$100 to US\$2.150 in Ecuador. Similarly, a recent study carried out by Wang (2017) affirms that a lack of resources impedes Chinese people from rural areas to achieve English language proficiently.

Lastly, the most negative factor against English learning motivation is the lack of businesses asking for proficient English speakers to be part of their staff. According to British Council (2015), there are few companies which employ professionals who speak English in Ecuador. Actually, those companies are located in Pichincha (58\%), Guayas (20\%), Azuay (15\%), Loja (4\%), El Oro (3\%) provinces. None are located in the Chimborazo province. As a result, English proficiency is not needed to get a regular job; and conversely, more than ever before, Chinese professionals want to achieve an English proficiency because of economic returns. International trade produces significant incomes which attracts, especially Chinese women from Coastal areas, to study English proficiently (Wang, 2017).

\section{A look at the Future}

The researchers strongly believe that each language is important in today's multicultural societies. Each language transmits a unique and irreplaceable worldview, as a way to understand and communicate people's realities (Corral, 2015). Speaking a second or more languages foster cognitive, social and linguistic development for students' benefits, especially in the academic field. Nonetheless, Crystal (2003) suggests that language death is part of a sociolinguistic reality too. Corral (2015) states that losing a language represents an irrevocable loss for humanity. Therefore, the indigenous peoples are the only ones that can revitalize their Kichwa language and culture; on the contrary, we are facing an unprecedented loss of Kichwa language. It is, therefore, vital to emphasize that Spanish or English should not be seen as a threat or superiority to any language; they serve to include other linguistically different societies, including multilingualism promotion (Pan, 2009).

\section{Conclusion}

The aim of this research was to find out university indigenous students' attitudes towards Kichwa, Spanish and English languages. The findings demonstrate a notorious difference in the students' language exposure towards those languages. University indigenous students present a remarkable interest for Spanish language which gives them more immediate social and academic advantage and mobility opportunities. Students quite often spend more time reading, listening, and interacting with Spanish speakers. That is, this minority population socially interacts by using the dominant language in social and academic settings. Even though, the mentioned above is a general fact among the scientific academic society, the findings of this current research ratify that fact. Kichwa code is mostly employed in family settings and sometimes in church. On the other hand, English code is learned and used as a compulsory subject in the university. Finally, indigenous students give little attention to learn English proficiently since professional employment demands do not require to speak English in any local business around the Chimborazo province. By the same token, the local context does not motivate indigenous learners to cultivate an interest in learning and speaking the English language. It can be concluded that the local, social and workplace context from the Chimborazo province do not demand people to speak English. 


\section{Implications and Recommendations}

In spite of the limited scope of the study, there are some pedagogical implications and recommendations.

- University administrators should take students' attitudes into account when designing English language curriculum and how it should be taught to indigenous students.

- Officials from the university should promote intercultural exchange between Ecuadorian college indigenous students and English speaking cultures all over the world through their International Relationship Department in the Universidad Nacional de Chimborazo.

- The study recommends further research on the effect indigenous students' motivation to study English more seriously for their own academic and social development.

- Indigenous students may become linguistic and socially competent in English as long as their English language exposure turns more meaningful in time and quantity. It is not enough to have many indigenous students who only know some survival English.

- Rejecting to be proficient in English, in today's globalized world, is a self-discrimination and self-denial to be part of a lingua franca speakers. More than before, there is such communication among nations and cultures for several reasons (commerce, technology, education among others) that translation and interpretation are less needed. Therefore, English has a long future in the planet.

- The effect of local teacher's professional training on language proficiency and new teaching trends might be important issue to be improved, especially for teaching minorities in university levels.

- Officials from government and university should promote linguistic policy implementation in order to encourage Kichwa language survival and its legal and cultural protection (Intercultural awareness), which is part of indigenous peoples' identity and worldview. Those policies will eliminate some socio/linguistic and negative attitudes between native and non-native Kichwa speakers.

- It is clear that the population of Chimborazo has to continue working on eradicating racial and linguistic discrimination against indigenous population.

- More than that, it is the indigenous population itself who should not be self-limiting with a total disinterest against English language. They should be aware of the importance of learning English as a globalizing language to improve their academic, professional, business and cultural opportunities instead.

\section{Acknowledgements}

We express our gratitude to indigenous university students who contributed with information to understand them under a sociolinguistic level in the scientific community.

\section{References}

AILLA. (2017, October). The Archive of the indigenous Languages of Latin America. Retrieved from The indigenous Languages of Latin America. Retrived from http://www.ailla.utexas.org/site/lg_about.html

Algeo, J., \& Acevedo Butcher, C. (2013). The Origins and Development of the English Language (7th ed.). In C. Learning (Ed.) Boston, United States of America: Wedsworth cengage learning.

Alseweed, M. (2012). University Students' Perceptions of the Influence of Native and Non-native Teachers. English Language Teaching, 11.

A. Alseweed, M. (2012). University Students' Perceptions of the Influence of Native and Non-native Teachers. English Language Teaching, 5(12).

Back, M. (2015). Transcultural Performance: Negotiating Globalized Indigenous Identities, Language and Globalization. United Kingdom: Palgrave Macmillan.

Back, M. (2015). Transcultural Performance.

Balderston, D., Gonzalez, M., \& Lopez, A. (2002). Encyclopedia of Contemporary Latin American and Caribbean Cultures. Routledge.

British Council. (2015, May). English in Ecuador. Retrieved from An examination of policy, perceptions and influencing factors. Retrieved from http://englishagenda.britishcouncil.org/sites/default/files/attachments/english_in_ecuador.pdf

Brown, D. (2001). Teaching by Principle. Englewood Cliffs, New Jersy: Prentice Hall.

Castillo, L. (2017). Dos idiomas se extinguieron en los últimos cinco años en el país. El Comercio, p. 1. 
Retrieved

from

http://www.elcomercio.com/tendencias/lenguasancestrales-extincion-andoa-zapara-intercultural.html

Cerron, P. R. (1987). Linguisitca Quechua (Second ed.). Cuzco, Peru, Perú: Centro de Estudios Rurales Andinos Bartolemé de las Casas.

Che, M. S., \& Yunus, M. (2014). Attitudes and Motivation Towards Learning English Among FELDA School Students. Australian Journal of Basic and Applied Sciences, 1-8.

Chireac, S. M., Francis, N., \& Hadley, S. (2016). Bilingüismo e interculturalidad, aprendizaje de segunda lengua y aprovechamiento escolar en la comunidad San Lucas de la provincia de Loja. Vinvestiga UTPL Memorias 2016, 244.

Corral, P. I. (2015). Indigenous Languages, Identity And Legal Framework In Latin. Procedia Social and Behavioral Sciences, 111-116.

Crystal, D. (2003). English as a global language (7th ed.). New York, United States: Cambridge University Press.

Cuasialpud, R. (2010). Indigenous Students' Attitudes towards Learning English through a Virtual Program: A study in a Colombian Public University. Universidad Nacional de Colombia, Facultad de Ciencias Humanas, Departamento de Lenguas Extranjeras, 12(2), 21.

Danver, S. (2015). Native Peoples of the World: An Encylopedia of Groups, cultures and Contemporany Issues. Routledge.

Duranti, A. (1997). Linguistic Anthropology. New York, United States of America: Cambridge University Press.

Eaton, S. E. (2011). How long does it Take to Learn a Second Language? Appying the "10.000-Hour Rule" as a Model for Fluency. ERIC, Institute of Education and Sciences, 1-10. Retrieved from https://www.springinstitute.org/

EcuadorUniversitario.com. (2016, march 20). EcuadorUniversitario. Retrieved from Ecuador tiene 736.000 estudiantes universitarios matriculados. http://ecuadoruniversitario.com

Ellis, R. (1994). The study of second language acquisition. (OUP, Ed.) Oxford, England: Oxford University Press.

Fasold, R. (2014). The politics of language. In R. Fasold, \& J. Connor Linton, An introduction to language and Linguistics (p. 563). United Kingdom: Cambridge University Press.

García, M. M., \& García Lecumberri, M. L. (2003). Age and the acquisition of English as a Foreign language (4th ed.). In D. Singleton, (Ed.), Great Britain, England: Cromwell Press Ltd.

Gass, S. M., \& Selinker, L. (2008). Second language acquisition, an introductory course (3d ed.). In S. M. Selinker (Ed.), New York and London: Routledge Taylor \& Francis Group.

Gil, A. Z. (n/d). academia.edu. Retrieved from Pervivencia y transformación de la tradicción oral Andina.

Guffante, T. (2015). Convenios para fomentar la movilidad de docentes y estudiantes. Riobamba: Universidad Nacional de Chimborazo.

Harmer, J. (2011). The practice of English language teaching. Longman ELT.

Holmes, J. (2013). An introduction to Sociolinguistics. London and New York: Taylor and Francis Group.

Hornberger, N., \& Coronel- Molina, S. (2006, 01 23). Quechua Language Shift, Maintenance, and Revitalization in the Andes: The case for Language Planing. University of Pennsylvania, 9-67. https://doi.org/10.1515/ijsl.2004.025

Hornberger, N. H., \& Coronel-Molina, S. M. (2004). Quechua language shift, maintenance, and revitalization in the Andes: the case for language planning. International Journal of the Sociology of Language.

Instituto Cervantes. (2012). Centro virtual Cervantes. Retrieved from El español: Una lengua viva.

Instituto Nacional de Estadísticas y Censo del Ecuador. (2010). Resultados del Censo 2010 de Población y Vivienda en Ecuador. Retrieved from INEC.

Instituto Nacional de Estadísticas y Censos, I. (2012, September 13). Resultados del Censo del 2010 de Población y Vivienda del Ecuador. Retrieved from Instituto Nacional de Estadísticas y Censos del Ecuador.

Kaur, P. (2014). Attitudes towards English as a Lingua Franca. Procedia - Social and Behavioral Sciences, 
214-221.

Lightbown, P., \& Spada, N. (2006). How languages are learned (3rd ed., Vol. III). Oxford: Oxford University Press.

Luykx, A., García Rivera, F., \& Julca Guerrero, F. (2016). Communicative strategies across Quechua languages. International Journal of the Sociology of language, 33.

Maya, E. N. (2014). Repositorio Digital Universidad De Las Américas: Lenguaje. Retrieved from Lenguaje Intercultural en el programa "Marcela Aprende Kichwa" transmitido en el 2014; estudio de caso

McLeod, S. (2014). SimplyPsychology. Retrieved from SimplyPsychology.

Mejía, A.-M. D. (2005). Bilingual Education in South America (Vol. 50). Toronto, Canada: Multilingual Matters LTD.

Mesinas, M., \& Perez, W. (2016). Cultural Involvement, Indigenous identity, and language: An exploratory study of Zapotec Adolescents and their Parents. Hispanic Journal of Behavioral Sciences, 25.

Mueller, R. (2012). Hamline University, Saint Paul, Minnesota.

Newton, J. (2009). Teaching ESL/ EFL listening and speaking. New York: Taylor and Francis Group.

Oliveros, N. (2008). Sobre la educación intercultural bilingue, las lenguas y los derechos linguisiticos. Docencia y contextos multiculturales, reflexiones y aportes para la formación de docentes desde un enfoque intercultural. (pp. 41-54). Canchis-Cusco,Perú: Tarea Asociación de publicaciones educativas.

OMICS International. (2013). OMICS International.

Palomino, S. (2015). Diglossia: The case of Quechua languages \& Spanish. Retrieved from The University of Utah, Department of Languages and Literature.

Pan, Y.-C. (2009). Test impact: English certification exit requirements in Taiwan. TEFLIN, 119-133.

Pearson Education Limited. (2007). Longman Advanced American Dictionary (2nd ed.). England: Pearson.

Pountain, C. (2016). Exploring the Spanish Language (2nd ed.). Routledge.

Quispe, C. (2014, Enero 04). Proceso de la enseñanza y aprendizaje de la lectura y escritura. Retrieved Noviembre $\quad 02, \quad 2014, \quad$ from http://www,lagaceta.com.ec/index.php/cultura/mensaje-para-undocente/12428-factores-que-coadyuvan-en-1 os-problemas-2

Rahimi, M., \& Hassani, M. (2012). Attitude towards EFL textbooks as a predictor of atitude towards learning English as a foreign language. Procedia-Social and Behavioral Sciences, 66-72.

Ralph, J. P. (2002). A history of the Spanish language. United Kingdom: Cambridge University Press.

Romaine, S. (2000). Language Change in Social Perspective. In S. Romaine, Language in Society Intro to Sociolinguisitcs (p. 281). New York: Oxford University Press.

Romero, R. H., Armijos Monar, J. G., Gonzalez Robalino, M. P., Heredia Arboleda, E. E., \& Ramos Samaniego, S. I. (2017). Eje transversal en la enseñanza de lenguas extranjeras en la Educación Superior. El caso de Ecuador. Red Iberoamericana de Pedagogía, 155-167.

Saroli, A. (2009). Defining Culture: Intercultural Bilingual Education. Retrieved from Intercultural Bilingual Education and the Officialization of Culture in Peru.

Saville, M. T. (2006). Introducing Second Language Acquisition. New York, UNited STates of America. Cambridge University Press.

Schilling, E. N. (2013). Dialect variation. In F. Ralph, \& J. Connor Linton (Eds.), An introduction to language and linguistics (p. 557). New York: Cambridge University Press.

Shukla, S., \& Connor Linton, J. (2006). Language change. In R. Fasold, \& J. Connor Linton (Eds.), An introduction to language and linguisitics (p. 557). New York: Cambrige University Press.

Spanish Language Domains. (2014, July 26). The numbers of Spanish Speakers in the World Exceeds 500 million. Retrieved from The numbers of Spanish Speakers in the World Exceeds 500 million. http://spanishlanguagedomains.com

Trawinski, M. (2005). An Outline of Second Language Acquisition Theories. Kraków: Wydawnictwo Naukowe Akademii Pedagogicznej. 
UCLA. (n/d). UCLA Language materials Project, teaching resources for less commonly taught languages. Retrieved from Quechua. http://www.lmp.ucla.edu/Profile.aspx?menu=004\&LangID=5

United Nations Department of Public Information. (2010, January 14). State of the World's Indigenous Peoples. Retrieved from Indigenous peoples make up one-third of the word's poorest and suffer alarming conditions in all countries. Retrieved from http://www.un.org/esa/socdev/unpfii/documents/SOWIP/press\%20package/sowip-press-package-en.pdf

Walsh, C. (2003). Interculturaidad crítica y (de)colonialidad. (Primera ed.). In E. D. Yala (Ed.) Quito, Ecuador: Dianyat.

Wang, H. (2017). The economic returns to proficiency in English China. China Economic Review, 91-104.

Yule, G. (2010). The study of the language (4th ed.). New York, United States of America: Cambridge University Press.

\section{Appendix}

Students' Questionnaire

Instructions: Here are some statements about language attitudes towards Kichwa, Spanish and English. Please answer by ticking $(\sqrt{ })$ only on one box of the right columns either: never, seldom, sometimes, almost always, or always. There are three statements in which you need to complete by providing your own words. Finally, there are three questions in which you have to tick $(\sqrt{ })$ on one box only.

Note!, there is no right or wrong answer. However, be honest with your responses.

Major:

Semester:

Gender: female male

Age:

Date:

\begin{tabular}{|c|c|c|c|c|c|c|}
\hline $\mathbf{N}^{\circ}$ & Questions & $\frac{\dot{d}}{z}$ & $\begin{array}{l}\Xi \\
\frac{\Xi}{\tilde{J}} \\
\tilde{E}\end{array}$ & 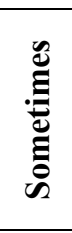 & 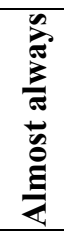 & $\sum_{\bar{\pi}}^{\tilde{\pi}}$ \\
\hline 1 & $\begin{array}{l}\text { How often do you use (Kichwa), (Spanish) } \\
\text { (English) in class? }\end{array}$ & & & & & \\
\hline 2 & $\begin{array}{l}\text { How often do you feel satisfied with your daily } \\
\text { progress in (Kichwa), (Spanish) (English) in } \\
\text { class? }\end{array}$ & & & & & \\
\hline 3 & $\begin{array}{l}\text { How often do you listen to auditory material in } \\
\text { your (Kichwa), (Spanish) (English) classes? }\end{array}$ & & & & & \\
\hline 4 & $\begin{array}{l}\text { How often do you read in your (Kichwa), } \\
\text { (Spanish) (English) classes? }\end{array}$ & & & & & \\
\hline 5 & $\begin{array}{l}\text { How often does your teacher speak in (Kichwa), } \\
\text { (Spanish) (English) to teach you? }\end{array}$ & & & & & \\
\hline 6 & $\begin{array}{l}\text { How often do you understand (Kichwa), } \\
\text { (Spanish) (English) language when your teacher } \\
\text { develops the class? }\end{array}$ & & & & & \\
\hline 7 & $\begin{array}{l}\text { How often do you use the internet to download } \\
\text { audios and readings in (Kichwa), (Spanish) } \\
\text { (English)? }\end{array}$ & & & & & \\
\hline
\end{tabular}




\begin{tabular}{|c|c|c|c|c|c|c|}
\hline & & $\frac{\dot{d}}{\grave{Z}}$ & 吾 & 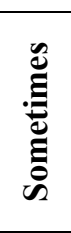 & 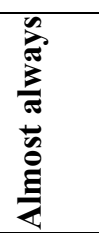 & 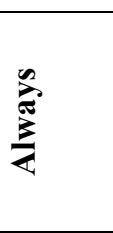 \\
\hline & News & & & & & \\
\hline & Information about your major & & & & & \\
\hline & Health & & & & & \\
\hline & Sports & & & & & \\
\hline 9 & $\begin{array}{l}\text { None of the topics mentioned above. } \\
\text { I prefer other topics to read in (Kichwa), (Spanish) }\end{array}$ & Eng & uch & & & \\
\hline 10 & How often do you hear (Kichwa), (Spanish) (Engli & h) ol & clas: & ics $\mathrm{r}$ & & \\
\hline & & $\frac{\dot{d}}{2}$ & 蒫 & 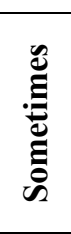 & 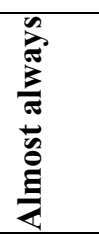 & $\frac{n}{4}$ \\
\hline & News & & & & & \\
\hline & Information about your major & & & & & \\
\hline & Health & & & & & \\
\hline & Sports & & & & & \\
\hline & Movies & & & & & \\
\hline & Documentaries & & & & & \\
\hline & Music videos & & & & & \\
\hline 11 & $\begin{array}{l}\text { None of the topics mentioned above. } \\
\text { I prefer other topics to listen to in (Kichwa), (Span }\end{array}$ & h) ( & h), s & & & \\
\hline 12 & & ¿্̀ & 吾 & 苛 & 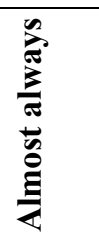 & $\sum_{i}^{\infty}$ \\
\hline & $\begin{array}{l}\text { How often do you interact personally with native } \\
\text { speakers of (Kichwa), (Spanish) (English) outside } \\
\text { class? }\end{array}$ & & & & & \\
\hline 13 & $\begin{array}{l}\text { How often do you use some social network (s) to } \\
\text { interact virtually with people who speak } \\
\text { (Kichwa), (Spanish) (English)? }\end{array}$ & & & & & \\
\hline 14 & $\begin{array}{l}\text { How often does your (Kichwa), (Spanish) (Englis } \\
\text { classes, such as: }\end{array}$ & & & ply s & interact & vities in \\
\hline & & $\dot{\bar{d}}$ & 吾 & 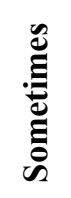 & 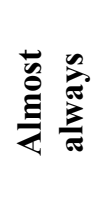 & $\sum_{i}^{\infty}$ \\
\hline & Games & & & & & \\
\hline & Group discussions & & & & & \\
\hline & Dramatizations & & & & & \\
\hline
\end{tabular}




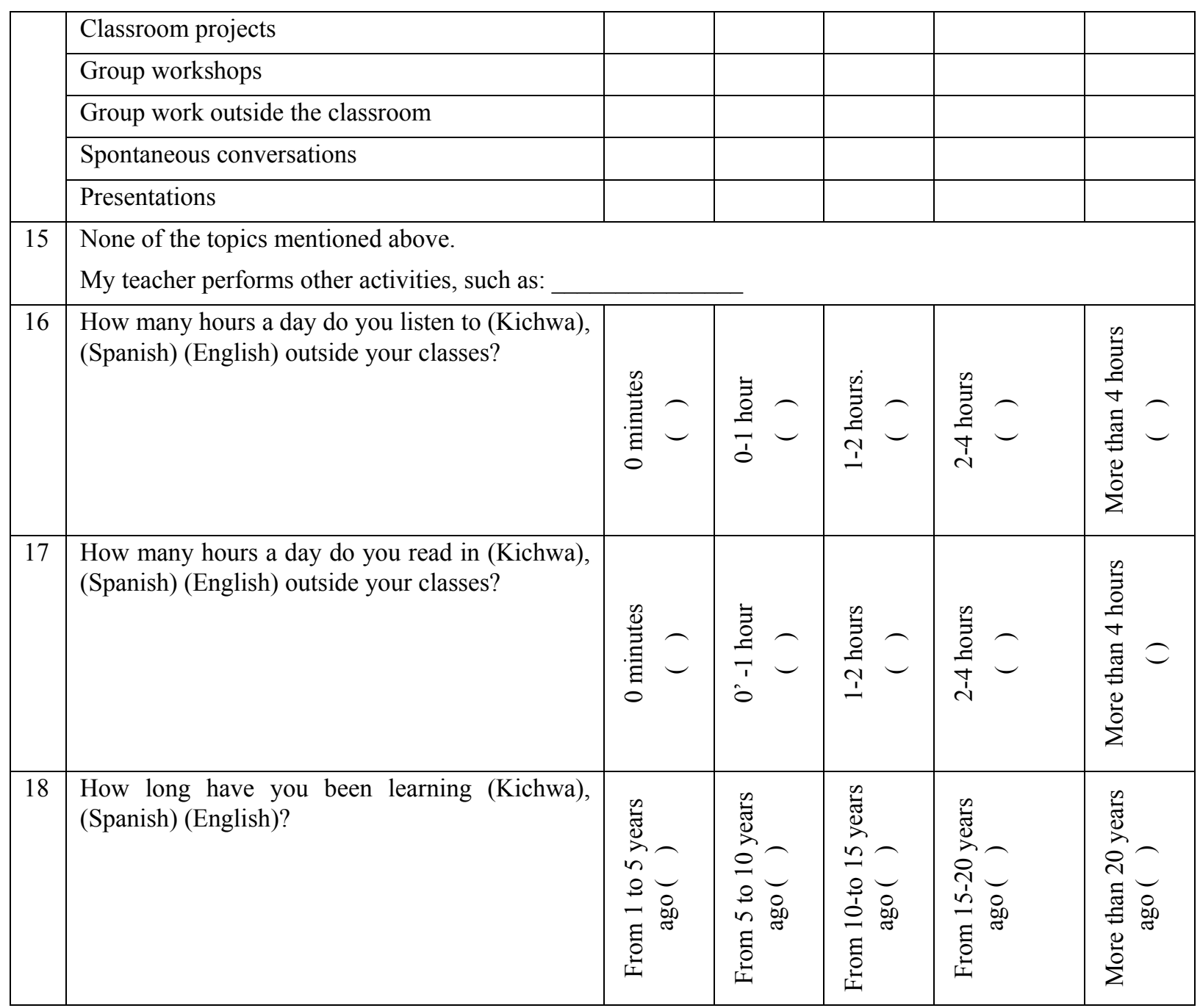

Thanks for your contribution

\section{Copyrights}

Copyright for this article is retained by the author(s), with first publication rights granted to the journal.

This is an open-access article distributed under the terms and conditions of the Creative Commons Attribution license (http://creativecommons.org/licenses/by/4.0/). 